\title{
Modulation of matrix metalloproteinase-9 and tissue inhibitor of metalloproteinase-1 in RAW264.7 cells by irradiation
}

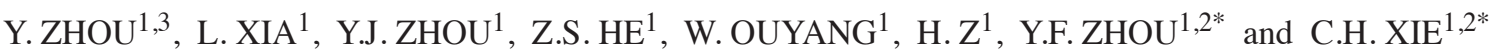 \\ ${ }^{1}$ Department of Radiation and Medical Oncology, ${ }^{2}$ Hubei Key Laboratory of Tumor Biological Behaviors, \\ Zhongnan Hospital, Wuhan University, Wuhan, Hubei 430071; ${ }^{3}$ Taihe Hospital, \\ Yunyang Medical College, Shiyan, Hubei 442000, P.R. China
}

Received April 6, 2010; Accepted June 2, 2010

DOI: $10.3892 / \mathrm{mmr} .2010 .326$

\begin{abstract}
Radiation-induced pulmonary injury is a severe complication affecting the quality of life of patients. Although the pathophysiology of the process is not fully understood, we hypothesized that it is potentially related to macrophages and their secretion of matrix metalloproteinase-9 (MMP-9). Macrophages are a type of inflammatory cell that synthesize hundreds of bioactive substances and enzymes. MMP-9 is closely involved in the maintenance of the basilar membrane, and leads to increased extracellular matrix deposition within the lung, which is a characteristic feature of radiation-induced lung fibrosis. We examined the role of ionizing radiation in modulating the production of MMP-9 in a macrophage cell line. RAW264.7 cells were irradiated with various doses of $\gamma$-rays, and then MMP-9 and tissue inhibitor of metalloproteinase-1 (TIMP-1) levels were determined at several time points. RT-PCR revealed a marked increase in the levels of MMP-9 mRNA, which peaked at $24 \mathrm{~h}$ post-irradiation and had begun to decline by $48 \mathrm{~h}$. By contrast, TIMP-1 mRNA experienced only a slight increase at $24 \mathrm{~h}$ post-irradiation, reaching significance at $48 \mathrm{~h}$ post-irradiation. Western blot analysis demonstrated an increased expression of MMP-9 protein in the irradiated cells, while TIMP-1 protein levels were not notably changed. Dexamethasone inhibited the increased expression of MMP-9 protein induced by ionizing radiation. These results indicate that MMP-9 expression by RAW264.7 cells, and an imbalance between MMP-9 and TIMP-1, may be involved in radiation-induced lung injury.
\end{abstract}

Correspondence to: Dr Cong-Hua Xie, Department of Radiation and Medical Oncology, Zhongnan Hospital, Wuhan University, 169 Donghu Road, Wuchang, Wuhan, Hubei 430071, P.R. China E-mail: chxie_65@hotmail.com

${ }^{*}$ Contributed equally

Key words: radiation-induced pulmonary injury, macrophages, matrix metalloproteinase-9, tissue inhibitor of metalloproteinase-1

\section{Introduction}

Radiation therapy is very important in the treatment of malignant neoplasms, especially those of the thorax. The lungs are relatively radiosensitive, making them the dose-limiting organ in therapeutic radiation. Radiation-induced pulmonary injury is a common complication of radiotherapy (1), and its precise pathophysiological mechanisms have yet to be established. Since macrophages produce numerous bioactive substances (2), Rubin et al (3) proposed that the inflammatory process involves an interplay of cellular interactions, a perpetual cascade of cytokines involved in radiation-induced pulmonary injury, including tumor necrosis factor- $\alpha$ (TNF- $\alpha$ ), interleukin-1 $\beta$ (IL-1 $\beta$ ), interleukin-6 (IL-6) and tumor growth factor- $\beta$ (TGF- $\beta$ ). It has been suggested that the disruption and alteration of the basement membrane plays a role in radiation-induced pulmonary injury (4). Matrix metalloproteinases (MMPs) are a large family of related proteolytic enzymes (5). MMP-2 and -9 are capable of degrading several components of the basement membrane in the lung interstitial matrix, including type IV collagen and fibronectin. They play a key role in the alteration of the basement membrane and in maintaining the integrity of the lung alveolar wall. MMP-2 is produced by endothelial cells. MMP-9 is produced by inflammatory cells, such as macrophages $(6,7)$, and not only promotes cellular migration, but activates cytokines such as TNF- $\alpha$ and IL-1 $\beta$. Yang et al (8) suggested that the overexpression of MMP-2 and -9 is involved in the inflammatory response of radiation-induced lung injury in vivo.

In previous studies, macrophages were found to be radioresistant and cell function was not affected by high-dose irradiation (9). McKinney et al (10) reported that $\gamma$-irradiation (0.5-10 Gy) alone did not induce nitric oxide (NO) production in J774.1 and RAW264.7 murine macrophages. However, human alveolar macrophages have been shown to release IL-1 within hours of irradiation in vitro (11), and low-dose irradiation to induce IL-1 and IL-6 expression in mouse macrophages in vitro (12). Araya et al (4) found that ionizing radiation enhanced the expression of MMP-2 in human lung epithelial cells in vitro, suggesting that MMP-2 is involved in radiation-induced lung injury. However, whether ionizing radiation stimulates macrophage cells in vitro to produce MMP-9 has yet to be determined. Therefore, in the present study, we 
analyzed the effect of ionizing radiation on the expression of MMP-9 and tissue inhibitor of metalloproteinase-1 (TIMP-1) in RAW264.7 cells.

\section{Materials and methods}

Materials. Cell culture dishes were purchased from Corning Inc. (Corning, NY, USA). Anti-MMP-9 (H-129) was purchased from Santa Cruz Biotechnology, Inc. (Santa Cruz, CA, USA). Anti-TIMP-1 (G-94) was purchased from Bioworld Technology, Inc. (Minneapolis, MN, USA ). A real-time PCR kit was purchased from Toyobo (Osaka, Japan), including ReverTra Ace- $\alpha$ (FSK-100) and SYBR Green real-time PCR master mix-plus-(QPK-212). Dex was purchased from Sigma (St. Louis, MO, USA).

Cell line and culture conditions. RAW 264.7 cells were obtained from the Cell Culture and Collection Center of Wuhan University. The cells were cultured in DMEM supplemented with $10 \%$ heat-inactivated FBS, $1 \%$ penicillin-streptomycin and $1 \%$ glutamine at $37^{\circ} \mathrm{C}$ in a $5 \% \mathrm{CO}_{2}$ atmosphere. The cells were placed in $35-\mathrm{mm}$ dishes $\left(1 \times 10^{6}\right)$, washed with phosphate buffered saline (PBS), and then incubated in serum-free DMEM with $1 \%$ penicillin-streptomycin and $1 \%$ glutamine for $24 \mathrm{~h}$. Upon reaching $80 \%$ confluence, cells were used in the following experiments.

Cell irradiation. Monolayer cultures of RAW264.7 cells were irradiated at room temperature using a $\mathrm{CO}^{60} \gamma$-ray unit at doses of $0,5,10$ and $20 \mathrm{~Gy}$ (at $1.39 \mathrm{~Gy} /$ minimum absorbed dose). After irradiation, the RAW264.7 cell cultures were returned to the incubator. The cell lysate was collected at different time points, and the levels of MMP-9 and TIMP-1 were estimated.

RT-PCR of MMP-9 and TIMP-1 mRNA. RT-PCR was used to determine the mRNA expression of MMP-9 and TIMP-1 with GAPDH as an internal control. Total RNA was obtained using a commercial kit (Toyobo) according to the manufacturer's instructions. To obtain cDNA, $2 \mu \mathrm{g}$ of total RNA were added to a 20- $\mu 1$ reaction mixture containing $2 \mu 1 \mathrm{RNA}, 4 \mu 1$ 5X RT Buffer $(25 \mathrm{mMMg}), 2 \mu 1 \mathrm{dNTP}(10 \mathrm{mM}), 1 \mu 1$ Oligo(dT)20 (10 pmol/ $/ \mu \mathrm{l}), 9 \mu 1$ RNase free $\mathrm{H}_{2} \mathrm{O}, 1 \mu 1$ Rnase inhibitor (10 U/ $\mu 1)$ and $1 \mu 1$ ReverTra Ace. PCR primers for mouse MMP-9 and GAPDH were as follows: MMP-9, 5'-AAGGGTACAGCC TGTTCCTGGT-3' (forward) and 5'-CTGGATGCCGTCTAT GTCGTCT-3' (reverse); GAPDH, 5'-CCGTGAAAAGAT GACCCAG-3' (forward) and 5'-TAGCCACGCTCGGTC AGG-3' (reverse); mouse TIMP-1, 5'-CCAGAAATCAACGAG ACCACC-3' (forward) and 5'-TACGCCAGGGAACCAAG AAG-3' (reverse). PCR was performed with $2.5 \mu 1$ of cDNA and $0.2 \mathrm{mM}$ primers using the following touchdown PCR protocol: 2 cycles of PCR at $95^{\circ} \mathrm{C}$ for $15 \mathrm{sec}, 58^{\circ} \mathrm{C}$ for $15 \mathrm{sec}$ and $72^{\circ} \mathrm{C}$ for $45 \mathrm{sec}$, followed by 40 cycles (MMP-9) or 40 cycles (GAPDH) of PCR at $95^{\circ} \mathrm{C}$ for $15 \mathrm{sec}, 58^{\circ} \mathrm{C}$ for $15 \mathrm{sec}$ and $72^{\circ} \mathrm{C}$ for $45 \mathrm{sec}, 2$ cycles of PCR at $95^{\circ} \mathrm{C}$ for $15 \mathrm{sec}, 59^{\circ} \mathrm{C}$ for $15 \mathrm{sec}$ and $72^{\circ} \mathrm{C}$ for $45 \mathrm{sec}$, followed by a final 40 cycles (TIMP-1) of PCR. Analysis of relative gene expression data was performed using real-time quantitative PCR and the $2^{-\Delta \Delta C T}$ method.

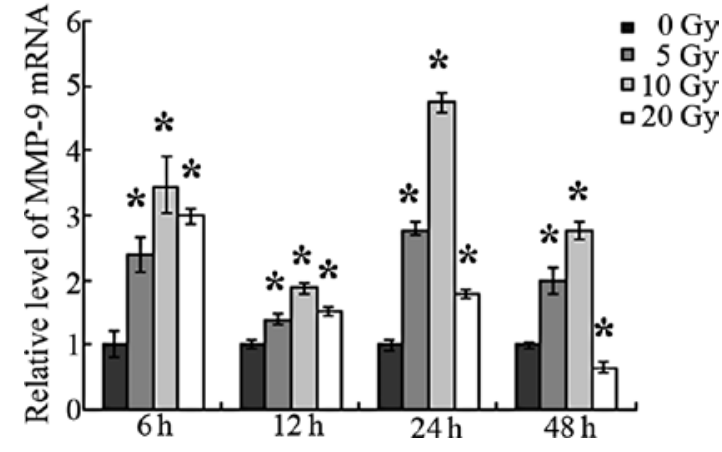

Figure 1. Effect of ionizing radiation on MMP-9 mRNA expression in RAW264.7 cells. Cells were irradiated with various doses of $\gamma$-rays $(0,5,10$ and $20 \mathrm{~Gy}$ ) and cultured at $37^{\circ} \mathrm{C}$. Total RNA was harvested at $6,12,24$ and $48 \mathrm{~h}$ post-irradiation. MMP-9 mRNA expression was analyzed using realtime PCR. Values are the means $\pm \mathrm{SD}(\mathrm{n}=3) ;{ }^{*} \mathrm{P}<0.05$, significantly different compared to non-irradiated controls.

Measurement of MMP-9 by Western blot analysis. The levels of MMP-9 protein in the cell lysate were measured by Western blotting. Cell lysate was heated at $100^{\circ} \mathrm{C}$ for $3 \mathrm{~min}$, subjected to $10 \%$ SDS-PAGE and transferred to nitrocellulose membranes with incubation overnight at $4{ }^{\circ} \mathrm{C}$ in Tris buffer containing 5\% non-fat dried milk. Subsequently, the membranes were incubated with the primary antibody to MMP-9 (1:200; H-129), followed by secondary antibody (1:3,000; goat anti-rabbit HRP-conjugated $\mathrm{Ab}$ ) and developed by ECL according to the manufacturer's instructions.

Measurement of TIMP-1 by Western blot analysis. The cell lysate was heated at $100^{\circ} \mathrm{C}$ for $3 \mathrm{~min}$, separated in $10 \%$ SDS-PAGE and transferred to nitrocellulose membranes. The membranes were incubated first with primary antibody to TIMP-1 (1:500; G-94) and then with secondary antibody $(1: 3,000$; goat anti-rabbit HRP-conjugated $\mathrm{Ab})$, after which the bands were identified with ECL reagent according to the manufacturer's protocol.

Data analysis. All experiments were repeated three times. Comparisons were made using one-way ANOVA with Fisher's post hoc test. Differences between means were evaluated with the Student's t-test. A P-value of $<0.05$ was considered significant.

\section{Results}

Radiation enhances MMP-9 $m R N A$ and protein expression in RAW264.7 cells. To determine whether radiation is a sufficient stimulus for the induction of MMP-9 production, RAW264.7 cells were irradiated at $0,5,10$ and $20 \mathrm{~Gy}$. Total RNA was assayed at $6,12,24$ and $48 \mathrm{~h}$ post-irradiation. After treatment with 5-10 Gy of $\gamma$-irradiation, MMP-9 expression in the RAW264.7 cells was significantly increased. At the various time points, total RNA was collected from irradiated and nonirradiated cells. MMP-9 mRNA was analyzed using real-time PCR. Fig. 1 shows that there were increased levels of MMP-9 mRNA in the irradiated compared to the non-irradiated cells. MMP-9 expression was most pronounced in cells treated with $10 \mathrm{~Gy}$ irradiation, and began to decline at $20 \mathrm{~Gy}$. A significant 


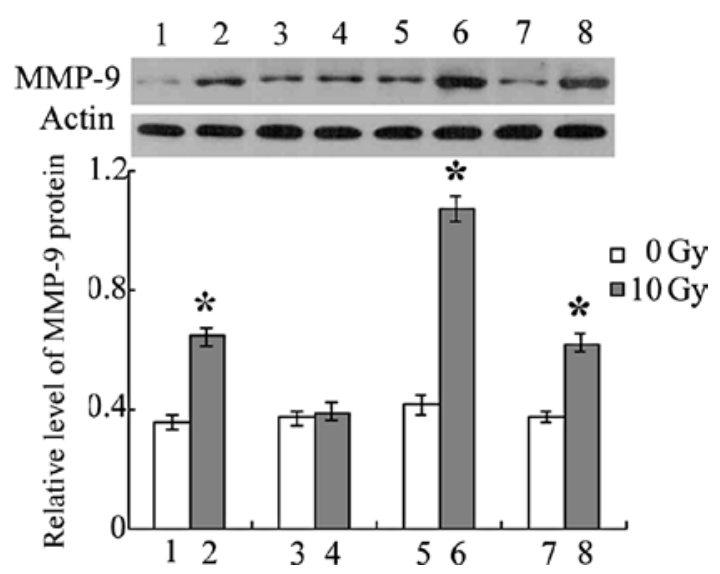

Figure 2. Effect of ionizing radiation on MMP-9 protein expression in RAW264.7 cells. Cells were irradiated with 10 Gy $\gamma$-rays and cultured at $37^{\circ} \mathrm{C}$. Total protein was harvested at $6 \mathrm{~h}$ (lane 2), $12 \mathrm{~h}$ (lane 4), $24 \mathrm{~h}$ (lane 6) and $48 \mathrm{~h}$ (lane 8) post-irradiation. MMP-9 protein expression was analyzed by Western blotting. Lanes 1, 3, 5 and 7 are control cells at $6,12,24$ and $48 \mathrm{~h}$, respectively. Values are the means $\pm \mathrm{SD}(\mathrm{n}=3) ;{ }^{*} \mathrm{P}<0.05$, significantly different compared to non-irradiated controls.

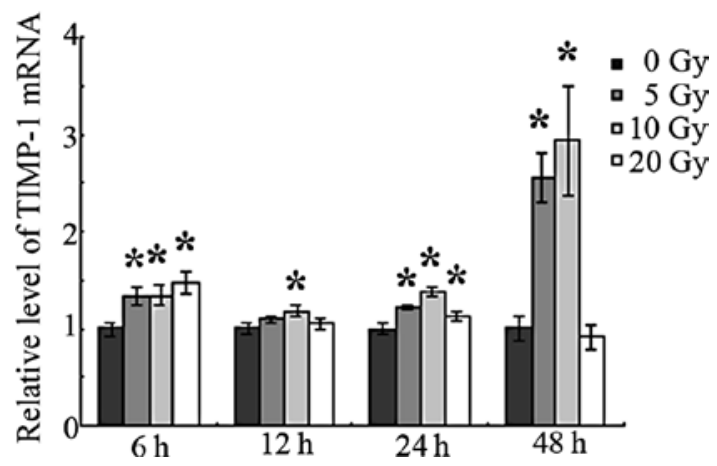

Figure 3. Effect of ionizing radiation on TIMP-1 mRNA expression in RAW264.7 cells. Cells were irradiated with various doses of $\gamma$-rays $(0,5,10$ and $20 \mathrm{~Gy}$ ) and cultured at $37^{\circ} \mathrm{C}$. Total RNA was harvested at $6,12,24$ and $48 \mathrm{~h}$ post-irradiation. TIMP-1 mRNA expression was analyzed using realtime PCR. Values are the means $\pm \mathrm{SD}(\mathrm{n}=3) ;{ }^{*} \mathrm{P}<0.05$, significantly different compared to non-irradiated controls.

increase in MMP-9 expression was observed starting at $6 \mathrm{~h}$ post-irradiation. Expression began to decrease at $12 \mathrm{~h}$ postirradiation, but remained higher than in the non-irradiated cells. Peak levels were reached $24 \mathrm{~h}$ after the initial exposure to ionizing radiation. At $48 \mathrm{~h}$, MMP-9 levels began to decline. These results indicate that ionizing radiation increases the expression of MMP-9 mRNA. To confirm the results, MMP-9 protein levels were determined using Western blotting. At the various time points, total protein was collected from irradiated and non-irradiated cells. Fig. 2 indicates that the results were consistent with those of the MMP-9 mRNA.

Radiation moderately increases TIMP-1 mRNA expression, but not TIMP-1 protein expression, in RAW264.7 cells. TIMP-1 transcript levels were determined in RAW264.7 cells irradiated at 0, 5, 10 and $20 \mathrm{~Gy}$. A slight increase in TIMP-1 mRNA transcript levels was observed at $24 \mathrm{~h}$ post-irradiation. As shown in Fig. 3, unlike MMP-9, TIMP-1 mRNA transcript

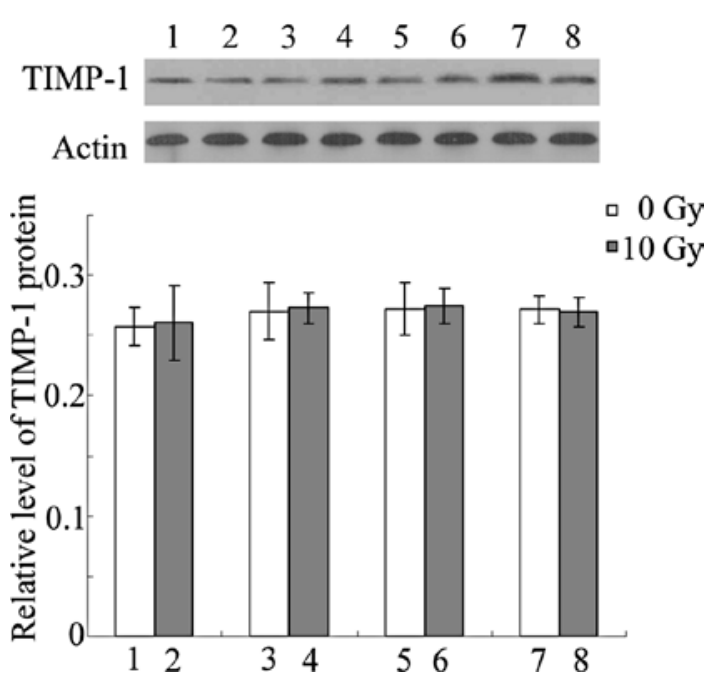

Figure 4. Effect of ionizing radiation on TIMP-1 protein expression in RAW264.7 cells. Cells were irradiated with $10 \mathrm{~Gy} \gamma$-rays and cultured at $37^{\circ} \mathrm{C}$. Cellular total protein was harvested at $6 \mathrm{~h}$ (lane 2), $12 \mathrm{~h}$ (lane 4), $24 \mathrm{~h}$ (lane 6) and $48 \mathrm{~h}$ (lane 8) post-irradiation. TIMP-1 protein expression was analyzed by Western blotting. Lanes 1, 3, 5 and 7 are control cells at 6,12 , 24 and $48 \mathrm{~h}$, respectively. Values are the means $\pm \mathrm{SD}(\mathrm{n}=3) ;{ }^{*} \mathrm{P}<0.05$, significantly different compared to non-irradiated controls.
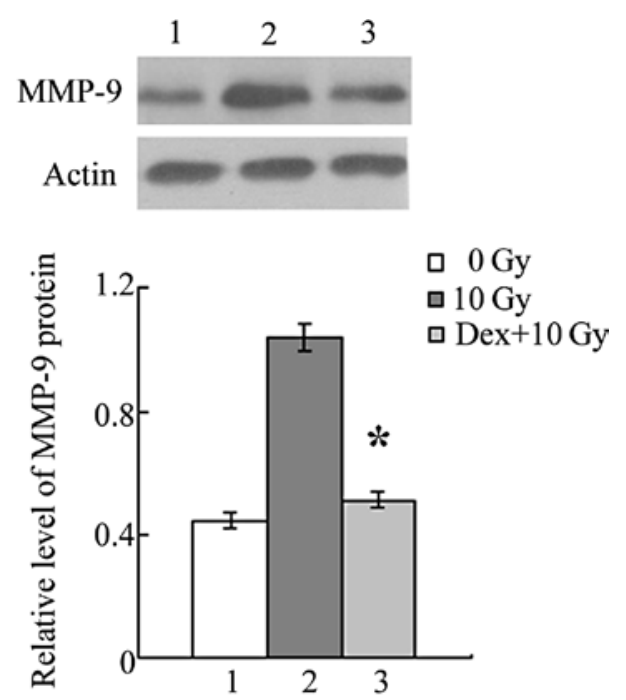

Figure 5. Effect of dexamethasone on MMP-9 production in ionizing radiation-stimulated RAW264.7 cells. Dexamethasone $(1 \mu \mathrm{M})$ was added to serum-free defined medium $1 \mathrm{~h}$ before treatment with $10 \mathrm{~Gy}$ ionizing radiation. Cells were cultured for an additional $24 \mathrm{~h}$, then total protein was collected and was subjected to Western blotting. Lane 1, blank control; Lane 2, irradiation; Lane 3, Dex+irradiation. Values are the means $\pm \mathrm{SD}$ $(n=3) .{ }^{*} \mathrm{P}<0.05$, significant difference between cells treated with dexamethasone and irradiation compared to cells treated with irradiation alone.

levels were not significantly altered at 6,12 or $24 \mathrm{~h}$ post-irradiaton in the irradiated compared to the non-irradiated cells; significance was only achieved at $48 \mathrm{~h}$ post-irradiaton. To determine whether the changes in TIMP-1 mRNA transcript levels coincided with protein production, TIMP-1 protein levels in serum-free media were determined using Western blotting. Fig. 4 indicates that there was no apparent increase in TIMP-1 protein levels at $48 \mathrm{~h}$ post-irradiation (Fig. 4), perhaps due to an in vitro post-translational modification of the protein. 
Dexamethasone suppresses the increase in MMP-9 expression induced by ionizing radiation in RAW264.7 cells. Since Dex is the primary drug used in the treatment of radiation pneumonitis, we examined its effect on the production of MMP-9 after ionizing radiation. Dex inhibited the increase in MMP-9 production caused by exposure to radiation (Fig. 5) $24 \mathrm{~h}$ after the initial exposure at $10 \mathrm{~Gy}$.

\section{Discussion}

Pneumonitis involves the aggregation of inflammatory cells and the degradation of extracellular matrix (ECM) components. Macrophages are the most important inflammatory effector cells and accumulate at sites of inflammation (13). MMP-9 and TIMP-1 play an important role in the regulation, turnover and remodeling of the ECM (5), and are therefore considered to play a crucial role in the pathophysiology of pulmonary inflammation and fibrosis $(8,14-16)$, in particular the overexpression of alveolar macrophage MMP-9 (16). In the present study, radiation had a dramatic effect on the up-regulation of MMP-9 protein, but did not affect TIMP-1 protein levels in the RWA264.7 cells. This suggests a disruption in the balance of MMP-9/TIMP-1, which leads to the excessive degradation of the ECM in the local lung environment, facilitating the influx of inflammatory cells. MMP-9 promotes cellular migration (17) and activates cytokines such as TNF- $\alpha$ and IL-1 $\beta$ (18). IL-1 $\beta$ (19) and TNF- $\alpha$ (20) play an important role in radiation-induced lung injury and, in RAW264.7 cells, regulate the expression of MMP-9, which may enhance the inflammatory response. We suggest that MMP-9 participates in and aggravates radiation-induced lung injury. In other types of lung inflammation, it was reported that non-selective MMP inhibitor reduced the development of bleomycin-induced fibrosis (21) and ventilator-induced lung injury (22) in mice.

It is believed that the production of MMP-9 is associated with a number of factors, such as the transcription factors AP-1 and nuclear factor- $\kappa \mathrm{B}(\mathrm{NF}-\kappa \mathrm{B})(23,24)$, reactive oxygen species (ROS) (19), IL-1 $\beta$ (19) and TNF- $\alpha$ (25). For macrophages, ionizing radiation activates transcription genes, such as NF-кB $(26,27)$, and induces the production of ROS (28), TNF- $\alpha$ and IL-1 (10-12). The MMP-9 gene promoter region contains a $\mathrm{NF}-\kappa \mathrm{B}$ motif (29); we therefore speculate that MMP-9 synthesis is closely related to NF- $\kappa \mathrm{B}$ expression. At $24 \mathrm{~h}$ post-irradiation, the production of MMP-9 reached its peak. MMP-9 expression may be associated with TNF- $\alpha$, since TNF- $\alpha$ is a key modulator of MMP-9. McKinney et al (10) found that TNF- $\alpha$ was not produced until $24 \mathrm{~h}$ postionizing radiation, and presented transiently. Nevertheless, in the present study, by $48 \mathrm{~h}$ post-irradiation, MMP-9 levels were slightly decreased. We therefore suggest that radiation damages DNA and alters signal transduction, and that these changes may affect the regulation MMP-9 expression. In irradiated cells, there was no apparent increase in TIMP-1 protein levels at $48 \mathrm{~h}$ post-irradiation. This may be related to an in vitro post-translational modification of the protein. TIMP-1 expression in different cell lines may vary, and the mechanisms of its expression require further study.

According to previous studies, macrophages are radioresistant cells whose cell functions are not affected by high-dose irradiation (9). McKinney et al (10) reported that $\gamma$-irradiation (0.5-10 Gy) alone did not induce NO production in J774.1 and RAW264.7 murine macrophages. However, in our experiment, macrophages activated by ionizing radiation led to functional changes.

In this study, we did not investigate the activity of MMP-9. The functions of MMP-9 in relation to TIMP-1 in radiationinduced pulmonary fibrosis require further clarification. However, our findings suggest that ionizing radiation enhances the expression of MMP-9 in RWA264.7 cells, and that cell functions were affected by irradiation. The clinical application of Dex is a fundamental treatment for radiation-induced pulmonary injury (1). Our data indicate that Dex is a potent inhibitor of MMP-9 protein expression induced by ionizing radiation. Taken together, the results of the present study support the hypothesis that MMP-9 producion by RAW264.7 cells may be deeply involved in acute lung injury due to radiation exposure. The mechanisms by which radiation stimulates MMP-9 production in RAW264.7 have yet to be elucidated; further study is required to determine the exact biochemical pathways responsible for each step of stimulation.

\section{Acknowledgements}

This study was supported by the National Natural Science Foundation of China (no. 30770653).

\section{References}

1. Movsas B, Raffin TA, Epstein AH and Link CJ Jr: Pulmonary radiation injury. Chest 111: 1061-1076, 1997.

2. Trott KR, Herrmann T and Kasper M: Target cells in radiation pneumopathy. Int Radiat Oncol Biol Phys 58: 463-469, 2004.

3. Rubin P, Johnston CJ, Williams JP, McDonald S and Finkelstein JN: A perpetual cascade of cytokines postirradiation leads to pulmonary fibrosis. Int J Radiat Oncol Biol Phys 33: 99-109, 1995.

4. Araya J, Maruyama M, Sassa K, Fujita T, Hayashi R, Matsui S, Kashii T, Yamashita N, Sugiyama E and Kobayashi M: Ionizing radiation enhances matrix metalloproteinase- 2 production in human lung epithelial cells. Am J Physiol Lung Cell Mol Physiol 280: L30-L38, 2001.

5. Van den Steen PE, Dubois B, Nelissen I, Rudd PM, Dwek RA and Opdenakker G: Biochemistry and molecular biology of gelatinase B or matrix metalloproteinase-9 (MMP-9). Crit Rev Biochem Mol Biol 37: 375-536, 2002.

6. Hoshino M, Nakamura Y, Sim J, Shimojo J and Isogai S: Bronchial subepithelial fibrosis and expression of matrix metalloproteinase-9 in asthmatic airway inflammation. J Allergy Clin Immunol 102: 783-788, 1998.

7. Visse R and Nagase H: Matrix metalloproteinases and tissue inhibitors of metalloproteinases: structure, function and biochemistry. Circ Res 92: 827-839, 2003.

8. Yang K, Palm J, Konig J, Seeland U, Rosenkranz S, Feiden W, Rübe $\mathrm{C}$ and Rübe CE: Matrix-Metallo-Proteinases and their tissue inhibitors in radiation-induced lung injury. Int $\mathrm{J}$ Radiat Biol 83: 665-676, 2007.

9. Schmidtke JR and Dixon FJ: The functional capacity of X-irradiated macrophages. J Immunol 108: 1624-1630, 1972.

10. McKinney LC, Aquilla EM, Coffin D, Wink DA and Vodovotz Y: Ionizing radiation potentiates the induction of nitric oxide synthase by IFN- $\gamma$ and/or LPS in murine macrophage cell lines: role of TNF- $\alpha$. J Leukoc Biol 64: 459-466, 1998.

11. O'Brien-Ladner A, Nelson E and Kimler BF: Release of interleukin-1 by human alveolar macrophages after in vitro irradiation. Radiat Res 136: 37-41, 1993.

12. Hosoi $Y$, Miyachi $H$ and Matsumoto $Y$ : Induction of interleukin- $1 \beta$ and interleukin- 6 mRNA by low doses of ionizing radiation in macrophages. Int J Cancer 96: 270-276, 2001.

13. Fujiwara $\mathrm{N}$ and Kobayashi K: Macrophages in inflammation. Curr Drug Targets Inflamm Allergy 4: 281-286, 2005. 
14. Manoury B, Nénan S, Guénon I, Lagente $\mathrm{V}$ and Boichot E: Influence of early neutrophil depletion on MMPs/TIMP-1 balance in bleomycin-induced lung fibrosis. Int Immunopharmacol 7: 900-911, 2007.

15. Kim JY, Choeng HC and Ahn C: Early and late changes of MMP-2 and MMP-9 in bleomycin-induced pulmonary fibrosis. Yonsei Med J 50: 68-77, 2009.

16. LemjabbarH, GossetP,Lechapt-Zalcman E,Franco-Montoya ML, Wallaert B, Harf A and Lafuma C: Overexpression of alveolar macrophage gelatinase B (MMP-9) in patients with idiopathic pulmonary fibrosis: effects of steroid and immunosuppressive treatment. Am J Respir Cell Mol Biol 20: 903-913, 1999.

17. Legrand C, Gilles C, Zahm JM, Polette M, Buisson AC, Kaplan H, Birembaut P and Tournier JM: Airway epithelial cel migration dynamics: MMP-9 role in cell-extracellular matrix remodeling. J Cell Biol 146: 517-529, 1999.

18. McCawley LJ and Matrisian LM: Matrix metalloproteinase: they are not just for matrix anymore. Curr Opin Cell Biol 13: 534-540, 2001

19. Yoo HG, Shin BA, Park JS, Lee KH, Chay KO, Yang SY, Ahn BW and Jung YD: IL-1beta induces MMP-9 via reactive oxygen species and NF-kappaB in murine macrophage RAW 264.7 cells. Biochem Biophys Res Commun 298: 251-256, 2002

20. Lee YS, Lan Tran HT and van Ta Q: Regulation of expression of matrix metalloproteinase- 9 by JNK in Raw 264.7 cells: presence of inhibitory factor(s) suppressing MMP-9 induction in serum and conditioned media. Exp Mol Med 41: 259-268, 2009.

21. Corbel M, Caulet-Maugendre S, Germain N, Molet S, Lagente V and Boichot E: Inhibition of bleomycin-induced pulmonary fibrosis in mice by the matrix metalloproteinase inhibitor batimastat. J Pathol 193: 538-545, 2001.
22. Kim JH, Suk MH, Yoon DW, Lee SH, Hur GY, Jung KH, Jeong HC, Lee SY, Lee SY, Suh IB, Shin C, Shim JJ, In KH, Yoo SH and Kang KH: Inhibition of matrix metalloproteinase-9 prevents neutrophilic inflammation in ventilator-induced lung injury. Am J Physiol Lung Cell Mol Physiol 291: 580-587, 2006.

23. Kim JH, Jeong JH, Jeon ST, Kim H, Ock J, Suk K, Kim SI, Song KS and Lee WH: Decursin inhibits induction of inflammatory mediators by blocking nuclear factor-kappaB activation in macrophages. Mol Pharmacol 69: 1783-1790, 2006.

24. Basu S, Pathak S, Pathak SK, Bhattacharyya A, Banerjee A, Kundu $\mathrm{M}$ and Basu J: Mycobacterium avium-induced matrix metalloproteinase-9 expression occurs in a cyclooxygenase2-dependent manner and involves phosphorylation- and acetylation-dependent chromatin modification. Cell Microbiol 12: 2804-2816, 2007

25. Lee JG, Lee SH, Park DW, Bae YS, Yun SS, Kim JR and Baek SH: Phosphatidic acid as a regulator of matrix metalloproteinase-9 expression via the TNF- $\alpha$ signaling pathway. FEBS Lett 581: 787-793, 2007.

26. Ibuki Y, Mizuno S and Goto R: $\gamma$-Irradiation-induced DNA damage enhances $\mathrm{NO}$ production via $\mathrm{NF}-\kappa \mathrm{B}$ activation in RAW264.7 cells. Biochim Biophys Acta 1593: 159-167, 2003.

27. Natarajan M, Mohan S, Konopinski R, Otto RA and Herman TS: Induced telomerase activity in primary aortic endothelial cells by low-LET gamma-radiation is mediated through NF-kappaB activation. Br J Radiol 81: 711-720, 2008.

28. Gallin EK and Green SW: Exposure to gamma-irradiation increases phorbol myristate acetate-induced $\mathrm{H} 2 \mathrm{O} 2$ production in human macrophages. Blood 70: 694-701, 1987.

29. Han YP, Tuan TL, Hughes M, Wu H and Garner WL: Transforming growth factor-beta and tumor necrosis factoralpha-mediated induction and proteolytic activation of MMP-9 in human skin. J Biol Chem 276: 22341-22350, 2001 